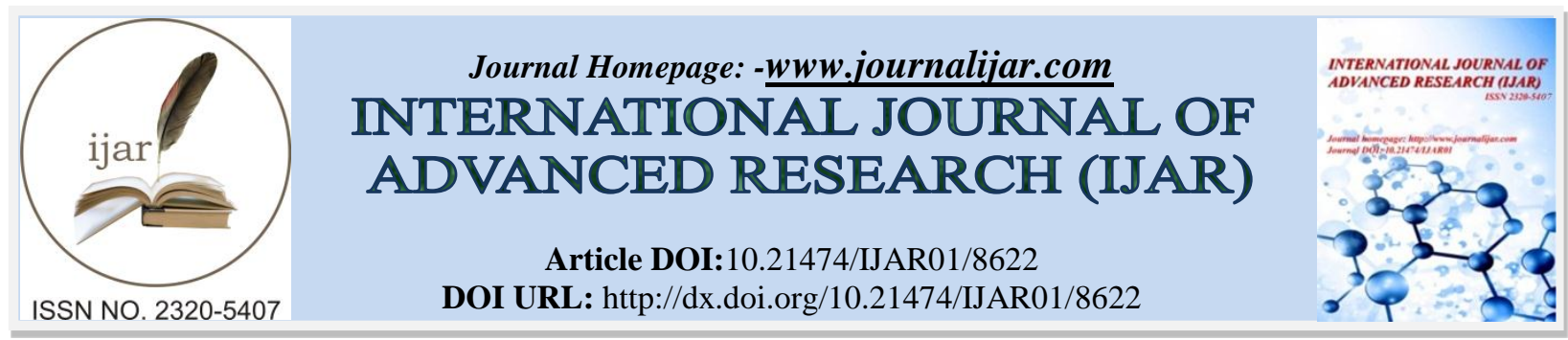

RESEARCH ARTICLE

\title{
THE DR FAMILY - AFIMBRIAL ADHESIN GENE IN UROPATHOGENIC ESCHERICHIA COLI ISOLATED FROM PATIENTS SUSPECTED WITH URINARY TRACT INFECTION.
}

\author{
SM.Nachammai ${ }^{1}$, Dr. Karthika Jayakumar ${ }^{2}$, Vinithra Suresh ${ }^{3}$, Kousalya.M ${ }^{3}$. \\ 1. SSSMCRI, Sri Balaji Vidhyapeeth University, Chennai. \\ 2. SSSMCRI, Shri Balaji Vidhyapeeth University, Chennai. \\ 3. SRDCH, Dr.MGR Medical University, Coimbatore.
}

\section{Manuscript Info}

\section{Manuscript History}

Received: 05 January 2018

Final Accepted: 07 February 2019

Published: March 2019

Key words:-

UPEC, afimbrial adhesin, afa gene, PCR.

\begin{abstract}
Background: Uropathogenic Escherichia coli (UPEC), possess different adhesin factors for binding the cells of urinary tract, afimbrial adhesin coded by the gene afa is one among the adhesin factors belonging to Dr adhesin family. afa facilitates the colonization by binding to the receptor on the Dr blood group antigen, it stimulates the cytopathic effect and various signal cascade reactions. This adhesin accounts for chronic and recurrence in UTI.

Aim \& Objective: The aim of the study is to determine the prevalence of afa gene by using molecular method PCR.

Materials \& Methods: Bacteria isolated from urine samples were processed and confirmed for E. coli using standard bacteriological methods. DNA extraction done followed by PCR amplication were processed for detection of afa genes using specific primer and the specific base pair bands were noted using gel documentation.

Results: The afa gene was found in 49 isolates $(23.1 \%)$ of UPEC out of 212 isolates, which were distributed among male patients 19(38.8\%) and $30(61.2 \%)$ in female patients with more prevalence among less than 20 years of age group.

Conclusion: afa, though a low frequency gene in UPEC showed high percentage in this study comparing the other geographical areas out of its low frequency.
\end{abstract}

Copy Right, IJAR, 2019,. All rights reserved.

\section{Introduction:-}

Uropathogenic Escherichia coli (UPEC) possess different types of fimbriae; P fimbriae, type1 fimbriae, S fimbrial adhesin, afimbrial adhesin etc., these adhesins helps the E. coli binding to the uroepithelial cells of the urinary tract [1]. Generally these adhesins helps in bacterial colonization of the urinary tract, strengthens the lodgment of bacteria by evading the hosts natural defense as well as immune mechanism [2]. The tubular filamentous form of UPEC helps in spreading of the bacteria to the adjacent cells. The Dr family of adhesins of $E$. coli is one of the urovirulence factor, facilitates the colonization and are associated with cystitis and pregnancy-associated pyelonephritis and also diarrhoeal disease The Dr adhesins includes (a) fimbrial adhesins, such as $\mathrm{Dr}$ haemagglutinin (O75X adhesin) and F1845; (b) afimbrial adhesins, such as AFA-I, AFA-II, AFA-III, AFA-IV binds to the Dr blood group antigen [3]. The afimbrial adhesin is a structural protein coded by the gene afa, this adhesin 
can only be detected by molecular method. The aim of the study is to determine the prevalence of afa gene in UPEC by PCR.

\section{Materials and methods:- \\ Bacterial isolates:}

A total of 212 E. coli isolated from suspected UTI patients were identified by standard culture using Blood agar, Mac Conkey agar and Hichrome agar and the biochemical identification processed were Catalase, Oxidase, Indole, Methylred - Voges prauskauer, Citrate, Urease, Triple sugar iron agar, Mannitol motility medium, glucose fermentation. Institutional Ethical Committee (IEC) approval was obtained and the study was progressed [4].

\section{Genotypic detection of papG and fimH gene by PCR:}

\section{DNA extraction:}

DNA extraction was performed by using boiling lysis method. E. coli isolates were cultured in Luria Bertani broth at $37^{\circ} \mathrm{C}$ for 18 hours. Bacteria were pelleted from $1.5 \mathrm{ml} \mathrm{LB}$ broth using centrifuge at $3000 \mathrm{rpm}$ then suspended in 200 $\mathrm{ml}$ of sterile deionized water and kept in water bath at $100^{\circ} \mathrm{C}$ for $10 \mathrm{~min}$. After centrifuging, the supernatant was used as template DNA and stored at $-20^{\circ} \mathrm{C}[5]$.

\section{PCR amplification:}

PCR amplification of virulence genes were used to reveal the prevalence of afimbrial adhesin, afa gene using specific primers. The amplification of virulence genes was carried out in a Thermal Cycler (Eppendorf Master Cycler) after standardizing the PCR conditions: an initial denaturation at $94^{\circ} \mathrm{C}$ for $2 \mathrm{~min}$, followed by 30 cycles of denaturation at $94^{\circ} \mathrm{C}$ for $1 \mathrm{~min}$, annealing at $60^{\circ} \mathrm{C}$ for $30 \mathrm{~s}$, and extension at $72^{\circ} \mathrm{C}$ for $1 \mathrm{~min} 30 \mathrm{sec}$, with a final extension at $72^{\circ} \mathrm{C}$ for $5 \mathrm{~min} .1$

\begin{tabular}{|l|l|l|l|l|}
\hline \multicolumn{2}{|l|}{ Table 1: afa gene primer sequence } \\
\hline $\begin{array}{l}\text { Dr adhesin } \\
\text { gene }\end{array}$ & \multicolumn{2}{l|}{ Primer sequence 5' - 3' } & $\begin{array}{l}\text { Base pair (bp) } \\
\text { size }\end{array}$ & Reference \\
\hline afa & F & CGGCTTTTCTGCTGAACTGGCAGGC & $672 \mathrm{bp}$ & $\begin{array}{l}\text { Soto et al., } 2011 \\
{[6]}\end{array}$ \\
\cline { 2 - 3 } & R & CCGTCAGCCCCACGGCAGACC & & \\
\hline
\end{tabular}

PCR products were then loaded in 1\% agar gel electrophoresis and amplified DNA fragments were detected by UV fluorescence transilluminator and the size of the amplicons was estimated by comparing with 100bp DNA ladder.

\section{Results:-}

All the bacterial isolates were identified using standard bacteriological methods. The afa gene was amplified using PCR with specific primers and the specified band of 672 bp on polyacrylamide gel compared with 100 bp ladder was determined to be the presence of afa gene (Figure 1). Afimbrial adhesin gene was found in 49 isolates (23.1\%) of UPEC out of 212 isolates.

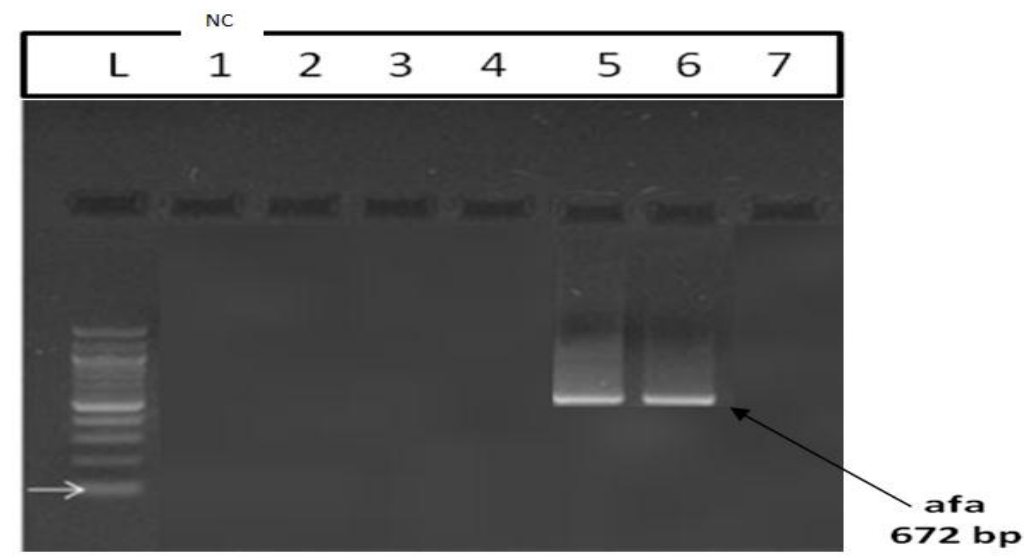

Figure 1: L, lane with 100bp ladder, Lane $1 \mathrm{NC}$ - negative control, Lane 5,6-afa gene positive 


\begin{tabular}{|l|l|l|}
\hline Table 2: Prevalence of virulence genes and their relation with sex \\
\hline \multirow{2}{*}{ Adhesin gene } & \multicolumn{2}{|c|}{ Sex } \\
\cline { 2 - 3 } & \multicolumn{1}{|c|}{ Male } & Female \\
\hline afa & $19(38.8 \%)$ & $30(61.2 \%)$ \\
\hline Total afa genes (of 212 E. coli) & \multicolumn{2}{c|}{$49(23.1 \%)$} \\
\hline
\end{tabular}

\begin{tabular}{|l|c|c|c|c|c|}
\hline \multicolumn{6}{|l|}{ Table 3: Prevalence of virulence genes according to age groups } \\
\hline Adhesin gene & Age group (years) & $\mathbf{2 1 - 4 0}$ & $\mathbf{4 1 - 6 0}$ & $\mathbf{6 1} \mathbf{- 8 0}$ & $>\mathbf{8 0}$ \\
\cline { 2 - 6 } & $\leq \mathbf{2 0}$ & $13(26.5 \%)$ & $14(28.6 \%)$ & $6(12.2 \%)$ & $1(2 \%)$ \\
\hline afa & $15(30.6 \%)$ &
\end{tabular}

The total of $49(23.1 \%)$ afa genes were distributed in the ratio of $19(38.8 \%)$ and $30(61.2 \%)$ among E. coli isolated from male and female patients respectively (Table 2). afa is more prevalent in the age group less than 20 years, followed by $41-60$ years $(28.6 \%)$ and least in the age group of $>80$ years (2\%), (Table 3$)$.

\section{Discussion:-}

Afimbrial adhesin of the Dr Family have a specific renal tissue tropism involved in UTI. It has a potential property which favors the establishment of chronic and recurrence of UTI, suggested by experimental and clinical findings [7]. These adhesins strength of binding is potential as it is responsible for chronic interstitial nephritis and chronic pyelonephritis [8].

The Dr Family afimbrial adhesin possess Afa-I and Afa-III found in many UPEC strains binds to the receptor on the Dr Blood group antigens present on the decay accelerating factor (DAF), which prevents the lysis of the cell by complement action. Once after binding to the host cells it activates signal pathways and cascade reactions and induces the cytopathic effect through development long cellular extensions wrapping around the adherent bacteria, which is the characteristic of Dr Family group of adhesins [2].

This study found the prevalence of 49 (23.1\%) of afa gene, which are distributed among $38.8 \%$ of male and $61.2 \%$ female patients where it is less in a study conducted by Mohajeri et al., $17(8.2 \%)$ afa genes, $9.5 \%$ and $8 \%$ among male and female respectively. Among age groups, the higher percentage were noted in $<20$ years $30.6 \%$, similar to the study Mohajeri et al., were the age group between 1-10 years and 11-20 years is higher comparing to other age groups.

\begin{tabular}{|c|c|c|l|}
\hline \multicolumn{4}{|c|}{ Table 4:- Distribution of afa gene in different areas referred from other studies } \\
\hline S.No. & Total no. of isolates & No. of Afa gene (\%) & References \\
\hline 1 & 162 & $10(6.2 \%)$ & Tiba et al., [9] \\
\hline 2 & 205 & $17(8.2 \%)$ & Mohajeri et al., [10] \\
\hline 3 & 72 & $7(9.7 \%)$ & Rahdar et al., [11] \\
\hline 4 & 60 & $16(26.7 \%)$ & Dormanesh et al., [12] \\
\hline 5 & 204 & $12(6 \%)$ & Oliveira et al., [13] \\
\hline 6 & 148 & $23(15.5 \%)$ & Munkhdelger et al., [14] \\
\hline 7 & 52 & $2(3.84 \%)$ & Ganimi [15] \\
\hline 8 & 172 & $30(17.4 \%)$ & Sughanda et al., [16] \\
\hline 9 & 112 & $6(5.4 \%)$ & Nader et al., [17] \\
\hline 10 & 150 & $0(0 \%)$ & Firozeeh et al., [5] \\
\hline 11 & 123 & $15(8.13 \%)$ & Karimian et al., [18] \\
\hline 12 & 150 & $27(18 \%)$ & Narmin et al., [19] \\
\hline 13 & 212 & $49(23.1 \%)$ & Present study \\
\hline
\end{tabular}

Table 4 represents the prevalence and distribution of afa genes in different areas. Though the prevalence of afa gene is less comparing to other adhesin factors, this afa gene distribution is higher in this study while reviewing other studies. So, the distribution of afa gene differed in different geographical regions. 


\section{Conclusion:-}

Afa gene, a low frequency gene found in UPEC compared to other adhesin genes. Noting the rate of prevalence of afa among different geographical areas, this study has higher percentage of afimbrial adhesin which is noted for its significance.

\section{References:-}

1. Wanderley Dias da Silveira, Fabiane Benetti, Marcelo Lancellotti, Alessandra Ferreira, Vera Nisaka Solferini \& Marcelo Brocchi. Biological and genetic characteristics of uropathogenic Escherichia coli strains, Rev. Inst. Med. trop. 2001; 43 (6):303-310.

2. Nowicki B, et al., 1993. Short consensus repeat-3 domain of recombinant decay-accelerating factor is recognized by Escherichia coli recombinant Dr adhesin in a model of a cell-cell interaction. J. Exp. Med. 178(6):2115-2121.

3. Selvarangan R, et al., 2000. Role of decay-accelerating factor domains and anchorage in internalization of Drfimbriated Escherichia coli. Infect. Immun.68(3):1391-1399.

4. Bailey \& Scott's, Diagnostic Microbiology. Chapter 22, Enterobacteriaceae, pp. 323-333.

5. Farzaneh Firoozeh, Mahmood Saffari, Foroogh Neamati, Mohammad Zibaei. Detection of virulence genes in Escherichia coli isolated from patients with cystitis and pyelonephritis. International Journal of Infectious Diseases, 2014; 29: 219-222

6. Soto SM, Zuniga S, Ulleryd P, and Vila J.Acquisition of Pathogenicity Island in an Escherichia coli clinical isolates causing febrile urinary tract infection, Eur J Clin Microbial Infect Dis. 2011;10: 1258-62.

7. Justyna Bien, Olga Sokolova and Przemyslaw Bozko Witold, Role ofUropathogenic Escherichiacoli Virulence Factors in Development ofUrinary Tract Infection and Kidney Damage. Review article, International Journal of Nephrology Volume 2012.

8. Goluszko P, et al., 1997. Dr fimbriae operon of uropathogenic Escherichia colimediate microtubule-dependent invasion to the HeLa epithelial cell line. J. Infect. Dis. 176(1):158-167.

9. Tiba, M.R. Yano, T. \& Leite, D.S. Genotypic characterization of virulence factors in Escherichia coli strains from patients with cystitis. Rev. Inst. Med. trop. S. Paulo 2008; 50(5): 255-260.

10. Mohajeri P, Khademi H, Ebrahimi R, Farahani A, Rezaei M. Frequency distribution of virulence factors in uropathogenic Escherichia coli isolated from Kermanshah in 2011-2012. Int J App Basic Med Res 2014;4:111-6.

11. Masoud Rahdar; Ahmad Rashki ; Hamidreza Miri, Comparison of the Common Adhesin Coding Operons Distribution in Uropathogenic and Phylogenetic Group B2 and A Escherichia coli Isolates, Avicenna J Clin Microb Infec. 2014; 1(3): e22981.

12. Banafshe Dormanesh ; Farhad Safarpoor Dehkordi ; Sahar Hosseini ; Hassan Momtaz ; Virulence Factors and OSerogroups Profiles of Uropathogenic Escherichia coli isolated from Iranian Pediatric Patients, Iran. Red Crescent Med J. 2014; 16(2): e14627.

13. F.A. Oliveira, K.S. Paludo, L.N.V.S. Arend, S.M.S.S. Farah, F.O. Pedrosa4, E.M. Souza, M. Surek, G. Picheth and C.M.T. Fadel-Picheth, Virulence characteristics and antimicrobial susceptibility of uropathogenic Escherichia coli strains. Genetics and Molecular Research, 2011; 10(4): 4114 - 4125.

14. Yandag Munkhdelger, Nyamaa Gunregjav, Altantsetseg Dorjpurev, Nishi Juniichiro, Jav Sarantuya. Detection of virulence genes, phylogenetic group and antibiotic resistance of uropathogenic Escherichia coli in Mongolia. J Infect Dev Ctries 2017; 11(1):51-57.

15. Ahmed K. A AL-Ganimi, Jawad K.T AL-Khafaji2 Karbala J. Some Virulence Factors Genes and Phylogenic Groups of Uropathogenic Escherichia Coli (UPEC) Isolated from Karbala Patients. Med. 2015; 9: (1).

16. Sugandha Srivastava, Jyotsna Agarwal, Bharti Mishra, Richa Srivastava. Virulence versus fitness determinants in Escherichia coli isolated from asymptomatic bacteriuria in healthy nonpregnant women. Indian Journal of Medical Microbiology, 2014; 34(1): 46-51.

17. Esam. G. M. Salih, Mohammed. I. Nader, Maarib. N. Rasheed, Rapid detection of uropathogenic Escherichia coli virulence factors in iraqi patients by multiplex polymerase chain reaction. World Journal of Pharmaceutical Research, 2015; 4: (12), 507-515.

18. Aazam Karimian, Hassan Momtazand Mahbobe Madani. Detection of uropathogenic Escherichia coli virulence factors in patients with urinary tract infections in Iran. African Journal of Microbiology Research, 2012; 6(39): 6811 6816.

19. Narmin S. Merza, Jaladet M. S., The Prevalence of Virulence Factors Among Uropathogenic Escherichia coli Strains Isolated From Different Hospitals in Kurdistan Region-Iraq. International Journal of Bioinformatics and Biomedical Engineering, 2015; 1: (3) 338-343. 